\title{
The Identification of a Novel, High Frequency Variant in the Cytochrome b Gene in an Isolated Population of a Rare Fish, Spined Loach Cobitis taenia, in England: A Population Worth Protecting?
}

\author{
R. Rahbari1, K. Tannahill2, C. Tobin², P. Robotham², I. D. Nicholl2* \\ ${ }^{1}$ Genome Mutation and Genetic Disease Group, The Wellcome Trust Sanger Institute, Wellcome Trust Genome Campus, \\ Cambridge, UK \\ ${ }^{2}$ Faculty of Science and Engineering, University of Wolverhampton, Wolverhampton, UK \\ Email: ^I.Nicholl@wlv.ac.uk
}

How to cite this paper: Rahbari, R., Tannahill, K., Tobin, C., Robotham, P. and Nicholl, I.D. (2017) The Identification of a Novel, High Frequency Variant in the Cytochrome b Gene in an Isolated Population of a Rare Fish, Spined Loach Cobitis taenia, in England: A Population Worth Protecting? Open Journal of Ecology, 7, 193-198. https://doi.org/10.4236/oje.2017.73014

Received: December 8, 2016

Accepted: March 12, 2017

Published: March 15, 2017

Copyright $\odot 2017$ by authors and Scientific Research Publishing Inc. This work is licensed under the Creative Commons Attribution International License (CC BY 4.0).

http://creativecommons.org/licenses/by/4.0/

\begin{abstract}
The spined loach Cobitis taenia, is listed as a protected species under Appendix 3 of the Bern Convention and Annex II of the European Council Directive (92/43/EEC) on the conservation of natural habitats and of wild fauna and flora. It is desirable therefore to understand the genetic diversity within European populations. In a molecular genetic analysis of the cytochrome $b$ gene in Cobitis taenia from three sites in the upper reaches of the River Trent catchment, a novel high frequency variant was identified which has not been previously reported in any European or Non-European population.
\end{abstract}

\section{Keywords}

mtDNA, Novel Haplotype, Conservation, Cobitidae

\section{(c) (i) Open Access}

\begin{abstract}
Spined loach Cobitis taenia L. 1758 is a small (up to $\sim 10 \mathrm{~cm}$ ) bottom dwelling fish that is generally found in areas of shallow, slow-flowing water and displays a preference for fine sandy substrate and patchy, dense macrophytic vegetation. Having a relatively short lifespan of only 3 to 4 years [1], the species relies heavily on annual recruitment to maintain populations. Limited swimming ability, along with the patchy distribution of suitable habitat, restricts the distribution of the species and potentially isolates populations. Phylogeographic studies can
\end{abstract}


help to establish historical genetic lineage and geographical distribution of a species [2] [3]. This information is vital to gain an understanding of taxonomic diversity and, in conjunction with ecological considerations, form conservation management strategies for rare or threatened species [4]. Genetic diversity can be considered within two different contexts: diversity within populations such as genetic drift, selection or inbreeding, or diversity among populations reflecting geographical structuring, with variation among populations due to local selection or adaptation, and to reduced gene flow or isolation.

Mitochondrial DNA (mtDNA) is well suited to studies of genetic diversity due to the maternal mode of inheritance and the high mutation rate. A number of studies have been carried out examining Cobitis spp. (e.g. [5] [6] [7] [8]) using mitochondrial DNA (mtDNA) analysis to determine phylogenetic relationships among European populations.

Studies conducted by Culling and Côte [6] and Culling et al. [3] aimed to infer phylogeographical patterns of Cobitis taenia through analysis of the mtDNA gene cytochrome $b$. Fifty one different haplotypes were identified as currently being present throughout the European populations and phylogenetic analysis indicated that after the last glacial maximum, three refuges in the Ponto-Caspian area of the Black Sea basin gave rise to two major lineages that re-colonised Europe. One of these lineages moved west, utilising the still present land bridge to colonise England in the upper part of the late Pleistocene. In England, C. taenia is only found in five easterly flowing river systems, and five sites have been selected as Special Areas of Conservation (SACs) for the conservation of representative populations [6] [9]. Temporal and spatial variations in the abundance and population structure at English sites have been recently reported [10]. The populations in the current study occur in the River Trent system near the western limit of the species' distribution in England. This study examined variation in the cytochrome $b$ sequence to assess the extent of genetic diversity on a small geographical scale.

\section{Materials and Methods}

The River Sow is a tributary of the River Trent. In a survey of the River Sow and one of its tributaries, the River Penk, in the Stafford area, three sites were identified where $C$. taenia were present (Table 1 and Figure 1). A total of 66 C. taenia was collected from these three sites using electro-fishing (pulsed DC). Fin clippings were taken from the right pectoral fin where possible (tail clipping if fish were small) and stored in $90 \%(\mathrm{v} / \mathrm{v})$ ultra-pure ethanol at $-20^{\circ} \mathrm{C}$ prior to further processing. Fish were returned alive to the river. Total DNA was extracted using the Nucleon Genomic DNA extraction kit HT (Tepnel Life Sciences, Manchester, UK) according to the manufacturer's instructions, dissolved in Tris-EDTA buffer ( $\mathrm{pH}$ 8.0) overnight at $4{ }^{\circ} \mathrm{C}$ and stored at $-20^{\circ} \mathrm{C}$ prior to further processing. For amplification of the entire cytochrome $b$ gene the primers used were adapted from [3]: the forward primer (GluDG. L) was 5'-TGACTTGAARAAC- 
Table 1. Sample site locations (Ordnance Survey coordinates) and novel Haplotype A frequencies.

\begin{tabular}{cccc}
\hline Site & Location & Sample Size & $\begin{array}{c}\text { Haplotype A (alanine) } \\
\text { Frequency }\end{array}$ \\
\hline 1 & $\begin{array}{c}\text { Radford Bridge, River Penk } \\
\text { SJ93889 21859 }\end{array}$ & 12 & 0.33 \\
2 & $\begin{array}{c}\text { Sow/Penk Confluence } \\
\text { SJ94924 22857 }\end{array}$ & 27 & 0.33 \\
3 & $\begin{array}{c}\text { Hold ford Bridge, River Sow } \\
\text { SJ97516 21547 }\end{array}$ & 27 & 0.44 \\
\hline
\end{tabular}

\section{Distance between Samples}

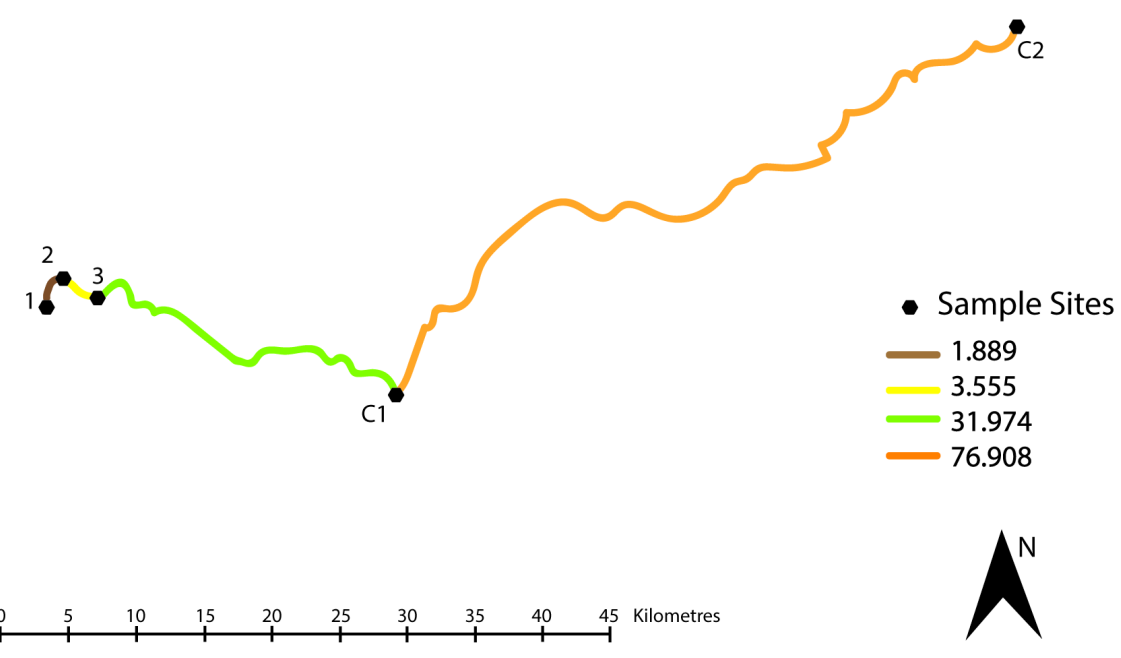

Figure 1. Location of the three sample sites on the Rivers Penk and Sow. Sites C1 and C2 are from the Culling et al., (2006) study. C1 is the River Mease, tributary to the River Trent and C2 is the River Trent at Stoke Bardolph.

CAYCGTTG-3' and the reverse primer (H16460) was 5'-CGAYCTTCGGATTAACAAGACCG-3' (Sigma-Genosys, Haverhill, UK). Approximately $100 \mathrm{ng}$ of DNA was used as a template in $50 \mu \mathrm{L}$ reactions and amplified using Amplitaq Gold (Applied Biosystems) under the following conditions: 1) $95^{\circ} \mathrm{C} / 12 \mathrm{~min} ; 2$ ) $95^{\circ} \mathrm{C} / 1 \mathrm{~min}$; 3) $55^{\circ} \mathrm{C} / 1 \mathrm{~min}$; 4$) 72^{\circ} \mathrm{C} / 1.5 \mathrm{~min}$;) Goto $2,34 \mathrm{X}$; 6) $72^{\circ} \mathrm{C} / 5 \mathrm{~min}$; $)$ $\left.32^{\circ} \mathrm{C} / 15 \mathrm{~min} ; 8\right)$ End. Some samples were amplified using approximately $100 \mathrm{ng}$ of DNA as a template in $50 \mu \mathrm{L}$ reactions containing an Expand HiFidelity PCR system (Roche Applied Science, Mannheim, Germany) under the following conditions: 1) $94^{\circ} \mathrm{C} / 2 \mathrm{~min}$; 2) $94^{\circ} \mathrm{C} / 15 \mathrm{sec}$; 3) $55^{\circ} \mathrm{C} / 30 \mathrm{sec}$; 4) $72^{\circ} \mathrm{C} / 1 \mathrm{~min}$; 5) Goto 2 , $32 \mathrm{X}$; 6) $72^{\circ} \mathrm{C} / 7 \mathrm{~min}$; 7) End. All PCR reactions were amplified using a PTC-100 (MJ research, Inc.) PCR engine. Amplification was confirmed by agarose gel electrophoresis. Samples were subsequently treated with ExoSAP-IT (USB Europe, Staufen, Germany) according to the manufacturer's instructions and incubated (1) $37^{\circ} \mathrm{C} / 15 \mathrm{~min}$; 2) $80^{\circ} \mathrm{C} / 15 \mathrm{~min}$; 3) End, using a PTC-100 PCR engine. 
Cycle sequencing was performed using BigDye (Applied Biosystems) chemistry employing the GluDG. L and the H16460 primer on a 3730 Applied Biosystems capillary electrophoresis sequencer (Applied Biosystems, Foster City, Ca, USA) at The Sequencing Service, University of Dundee (Dundee, UK).

\section{Results}

The complete mitochondrial cytochrome $b$ gene was amplified and sequenced in forward and reverse directions from 66 samples collected from three locations in the upper reaches of the River Trent catchment (Table 1). The amplicon was approximately $1200 \mathrm{bp}$ in length. BLASTN analysis with Build 2.2.30 [11] [12] of the 1140 base pair nucleotide sequence confirmed successful amplification of the cytochrome $b$ gene, with identity to the mitochondrial cytochrome $b$ sequence previously published by [2] (accession number AY191565) and the previously reported Haplotype "1" [3] (AY735185.1) from UK sites For clarity it should be noted that the first codon reported for the Culling et al. paper is 15 nucleotides down-stream (encoding for lysine) from the sequence described herein. Unexpectedly however, a significant proportion of samples from the sites examined in the current study possessed a variation not reported in previously published haplotypes. This was a single nucleotide polymorphism, m.1091T > C (GTA > GCA), which is translated as p.Val364Ala. (amino acid altered from valine to alanine at codon 364). The nucleotide sequence (herein denoted as Haplotype "A") has been deposited under GenBank accession number KR003441.

This variant is theoretically a conservative substitution at the amino acid level, and in-silico analysis employing Provean v1.1.3 [13] suggests that the variation is indeed neutral in effect. The variant has not been reported before in any of the haplotypes previously assigned to English [3] or European populations of C. taenia or to Cobitis spp.; indeed, the authors are only aware of a change in the amino acid at this location (isoleucine instead of valine) in Cobitis choii (Blast Pbuild 2.2.30) suggesting that, at least in Cobitis spp. little genetic drift is generally seen to occur at this particular codon, and thus highlighting the uniqueness of this reported haplotype.

This finding has potential implications for conservation measures for $C$. taenia in this catchment. The proportion of the polymorphism (Haplotype "A") versus wild type at the various locations is indicated in Table 1 . The overall frequency of the variant was 0.38 .

\section{Discussion}

This study has identified a novel haplotype of mitochondrial cytochrome $b$ in an English population of $C$. taenia. The resulting change in amino acid should not result in a significant change in the cytochrome b protein function as both amino acids have similar physico-chemical properties. This would suggest that perhaps the polymorphism is due to genetic drift rather than natural selection as no fitness benefit is apparently evident [14], however, the relatively high frequency of this variant may suggest that there is a founder effect in action. Indeed, in the 
River Mease, a tributary further downstream on the River Trent, all fish were described as Haplotype "1" [3]. Figure 1 shows the distance in river kilometres between the three sites in the current study and the two sites downstream, denoted C1 (River Mease) and C2 (River Trent at Stoke Bardolph), studied by Culling et al. [3]. The three current sample sites are within $5.5 \mathrm{~km}$ of each other and $32 \mathrm{~km}$ upstream of site $\mathrm{C} 1$ and $109 \mathrm{~km}$ upstream of site C2.

With respect to conservation of this population of a rare fish in the UK, opposing arguments as to the conservation priorities regarding small populations showing genetic variation persist, and are worth consideration. While arguments can be made that conservation efforts in this direction may "run the risk of protecting genetic variation favoured by idiosyncratic local selection regimes or produced by non-adaptive mechanisms", Willi et al. also suggest that perhaps small populations may arise through exposure to more diverse environmental conditions, and represent reservoirs of genetic variation adaptive within a potentially wide range of environments [14]. In this case, conservation efforts would protect individuals that are genetically and ecologically distinct. When considering populations within the River Mease and River Witham, Culling and Côté [6] state that the discovery of haplotypes not found elsewhere in Europe make these sites crucial marginal areas for spined loach conservation. They state, "from a genetic perspective, marginal populations may be particularly important in conservation because they could act as a reservoir of potential to adapt to changing environment and climate". The presence of this high frequency variant can be used as a marker to explore the geographical extent of these populations and the connectivity between populations. It will allow study of whether these populations comprise part of a meta population, which will have implications for the most appropriate conservation approach. These results also raise the issue as to whether this polymorphism is a marker of fitness or reflects neutral genetic drift; further study could focus on the examination of sites downstream of the ones utilised herein in an attempt to answer this question.

\section{Acknowledgements}

We wish to thank D. Luckhurst for assistance with preparation of Figure 1, A. Black for assistance in the field and C. Young for comments on the manuscript.

\section{References}

[1] Robotham, P. (1981) Age, Growth and Reproduction of a Population of Spined Loach, Cobitis taenia (L.). Hydrobiologia, 85, 129-136. https://doi.org/10.1007/BF00006622

[2] Bohlen, J., Perdices, A., Doadrio, I. and Economidis, P.S. (2006) Vicariance, Colonisation, and Fast Local Speciation in Asia Minor and the Balkans as Revealed from the Phylogeny of Spined Loaches (Osteichthyes; Cobitidae). Molecular Phlyogenetics and Evolution, 39, 552-561. https://doi.org/10.1016/j.ympev.2005.12.007

[3] Culling, M.A., Janko, K., Boron, A., Vasil'ev, V.P., Côté, I.M. and Hewitt, G.M. (2006) European Colonization by the Spined Loach (Cobitis taenia) from PontoCaspian Refugia Based on Mitochondrial DNA Variation. Molecular Ecology, 15, 
173-190. https://doi.org/10.1111/j.1365-294X.2005.02790.x

[4] Moran, P. (2002) Current Conservation Genetics: Building an Ecological Approach to the Synthesis of Molecular and Quantitative Genetic Methods. Ecology of Freshwater Fish, 11, 30-55. https://doi.org/10.1034/j.1600-0633.2002.110105.x

[5] Ludwig, A., Bohlen, J., Wolter, C. and Pitra, C. (2001) Phylogenetic Relationships and Historical Biogeography of Spined Loaches (Cobitidae, Cobitis and Sabanejewia) as Indicated by Variability of Mitochondrial DNA. Zoological Journal of the Linnean Society, 131, 381-392. https://doi.org/10.1111/j.1096-3642.2001.tb02242.x

[6] Culling, M.A. and Côté, I.M. (2005) Genetics and Ecology of Spined Loach in England: Implications for Conservation Management. Environment Agency Science Report Series No. SC000026/SR.

[7] Janko, K., Flajshans, M., Choleva, L., Bohlen, J., Slechtova, V., Rabova, M., Lajbner, Z., Slechta, V., Ivanova, P., Dobrovolov, I., Culling, M., Persat, H., Kotusz, J. and Rab, P. (2007) Diversity of European Spined Loaches (genus Cobitis L.): An Update of the Geographic Distribution of the Cobitis taenia Hybrid Complex with a Description of New Molecular Tools for Species and Hybrid Determination. Journal of Fish Biology, 71, 387-408. https://doi.org/10.1111/j.1095-8649.2007.01663.x

[8] Perdices, A., Bohlen, B. and Doadrio, I. (2008) The Molecular Diversity of Adriatic Spined Loaches (Teleostei, Cobitidae). Molecular Phylogenetics and Evolution, 46, 382-390. https://doi.org/10.1016/j.ympev.2007.05.007

[9] Perrow, M.R. and Jowitt, A.J.D. (1997) The Habitat and Management Requirements of Spined Loach (Cobitis taenia). English Nature Research Report No. 244.

[10] Nunn, A.D., Tewson, L.H., Bolland, J.D., Harvey, J.P. and Cowx. I.G. (2014) Temporal and Spatial Variations in the Abundance and Population Structure of the Spined Loach (Cobitis taenia), a Scarce Fish Species: Implications for Condition Assessment and Conservation. Aquatic Conservation: Marine and Freshwater Ecosystems, 24, 818-830.

[11] Zhang, Z., Schwartz, S., Wagner, L. and Miller, W. (2000) A Greedy Algorithm for Aligning DNA Sequences. Journal of Computational Biology, 7, 203-214.

[12] Morgulis, A., Coulouris, G., Raytselis, Y., Madden, T.L., Agarwala, R. and Schäffer, A.A. (2008) Database Indexing for Production MegaBLAST Searches. Bioinformatics, 24, 1757-1764.

[13] Choi, Y., Sims, G.E., Murphy, S., Miller, J.R. and Chan, A.P. (2012) Predicting the Functional Effect of Amino Acid Substitutions and Indels. PLOS ONE, 7, e46688. https://doi.org/10.1002/aqc.2451

[14] Willi. Y., Van Buskirk, J., Schmid, B. and Fischer, M. (2007) Genetic Isolation of Fragmented Populations Is Exacerbated by Drift and Selection. Journal of Evolutionary Biology, 20, 534-542. https://doi.org/10.1089/10665270050081478 
Submit or recommend next manuscript to SCIRP and we will provide best service for you:

Accepting pre-submission inquiries through Email, Facebook, LinkedIn, Twitter, etc. A wide selection of journals (inclusive of 9 subjects, more than 200 journals)

Providing 24-hour high-quality service

User-friendly online submission system

Fair and swift peer-review system

Efficient typesetting and proofreading procedure

Display of the result of downloads and visits, as well as the number of cited articles Maximum dissemination of your research work

Submit your manuscript at: http://papersubmission.scirp.org/

Or contact oje@scirp.org 